UDC: $316.61: 316.356 .2-053.81-058.8$

DOI: https://doi.org/10.24195/2414-4665-2017-3-7

Vadym Zavatskyi,

PhD (Candidate of Psychological Sciences), associate professor, Department of Practical Psychology and Social Work, Volodymyr Dahl East Ukrainian National University, 59A, Tsentralnyi Avenue, Severodonetsk, Ukraine,

Anatoliy Tkach,

Dr hab., professor, Department of Theoretical Economics, Rzeszow University of Technology,

12, Powstańców Warszawy Str., 35-959, Rzeszow, Poland,

Andrii Fedorov,

Vice-rector, Volodymyr Dahl East Ukrainian National University,

59-a, Zentralnyi avenue, Severodonetsk, Ukraine

\title{
SOCIO-PSYCHOLOGICAL PRINCIPLES OF SUPPORTING PERSONALITY'S SUBJECTIVE WELL-BEING IN CONTEMPORARY SOCIETY
}

The paper aims to analyse the principles of the development and functioning of the integrated socio-psychological programme of supporing subjective well-being of a married person. Psychocorrection involved 52 participants (26 married couples) who formed the experimental group (EG) and 54 participants (27 couples) who formed the control one (CG). The participants of the study were divided into the groups on a voluntary basis. The participants of the control group did not undergo any psychocorrectional treatment. The participants of the experimental group were divided into 5 subgroups, each of them consisting of 8-12 people. During 6 months, each subgroup attended psychocorrectional sessions twice a week; after that, the sessions were conducted once a week for 6 months more. The programme was being implemented in three successive stages, each of them included thematic, organisational and reflexive substages and was represented by a set of sessions targeted at achieving a certain goal. Qualitative and quantitative analysis of the data obtained after formative impact makes it possible to conclude that the chosen methods of psychological aid in socio-psychological support of subjective well-being of a married person are effective for solving the following problems: increasing the level of emotional comfort; self-fulfilment in marriage at the operational level, the level of values and role sets; optimism; moral motivation; development of reflexion, internality, self-analysis skills, the ability to differentiate and express one's emotions; expanding the experience in conflict-free communication in the system of interpersonal familial role-based interaction of spouses, orientation at self-actualisation; increasing the general integrated index of satisfaction with marriage.

Keywords: a personality, subjective well-being, counselling, psychocorrection, psychotherapy.

\section{Introduction}

Under conditions of the reforming of all life spheres and rapid social changes taking place in contemporary society, the study of subjective well-being is gaining relevance, which is caused by the need for finding the basis for maintaining personality's inner balance, the structure of subjective well-being and its components as well as distinguishing methods of psychological aid in supporting personality's subjective well-being. The issue of subjective well-being has not been studied until recent years; so far, it has been investigated mostly by foreign scientists.

Interpersonal interaction in marriage is the prerequisite for subjective well-being of a married person, which, in its turn, is associated with the place of a family in the life of the society and individual person. Psychological well-being in a family becomes difficult because of each spouse's ambition to satisfy, first of all, his/her own needs and lack of coordination of actions in intrafamilial activities, which leads to destabilisation of marital relations and dissatisfaction with them. Therefore, the issues of socio-psychological peculiarities of supporting personality's subjective well-being under conditions of problems existing in today's transformational society are worth investigating.

Researchers note that the quality of marital relations depends greatly on spouses' compatibility, their social and psy- chophysical suitability, shared outlook, attitudes and habitual forms of reaction in their parents' families (I. Horbal, E. Diner, Yu. Dmytruk, M. Yeleiko, R. Inglehart, O. Kliapets, E. Kolohryvova, H. Puchkova). Marital well-being is determined, in particular, by the feeling of subjective satisfaction of married couple with their marital relations (Yu. Aloshina, V. Bocheliuk, L. Hozman, T. Hovorun, H. Dubchak, O. Kaminska, L. Moroz, I. Khitrina, N. Khloponina, T. Trapeznikova, P. Yakobson and others).

Besides, the issue of creating an integrated sociopsychological programme of supporting subjective wellbeing in marriage has not been investigated in social psychology as the subject of a special study.

The paper aims to analyse the principles of development and functioning of the integrated sociopsychological programme of supporing subjective wellbeing of a married person. The key task of the research is to specify the content and efficiency of implementing the integrated socio-psychological programme of supporting subjective well-being of a married person.

Research methods

The principal theoretical and methodological approaches to the issue of personality's subjective well-being are the following: targeted approach that associates subjective well-being with orientation at the final target or sub- 
ject of the need; axiological approach, according to which activity motives determine correlation between certain values and activity results instead of the motive of aiming for well-being; cognitive approach, in which experiencing subjective well-being is explained by means of cognitive principles or properties of events taking place in ones' life; socio-psychological approach based on studying the impact of socio-psychological factors on personality's subjective well-being (the determining factor is social standard model of social comparison); personal approach, in which subjective well-being is considered as a trait or propensity of a personality; and situational approach, according to which subjective well-being is considered as a temporary state that depends on a certain situation.

\section{Discussion}

Psychocorrection involved 52 participants (26 married couples) who formed the experimental group (EG) and 54 participants (27 couples) who formed the control one (CG). The participants of the study were divided into the groups on a voluntary basis. Participants of the control group did not undergo any psychocorrectional treatment. Participants of the experimental group were divided into 5 subgroups, each of them consisting of 8-12 people. During 6 months, each subgroup attended psychocorrectional sessions twice a week; after that, the sessions were conducted once a week for 6 months more.

The programme was being implemented in three successive stages, each of them included thematic, organisational and reflexive substages and was represented by a set of sessions targeted at achieving a certain goal. At the same time, these stages were parts of the integrated programme, and every next step continued the previous ones and as a result made it possible to provide continuous, systematic socio-psychological support of subjective well-being for the participants of the experimental group. The logic of the programme structure involved its gradual complication, taking into account the participants' capabilities and dynamics of the group progress. Complication of the programme appeared as a factor stimulating the participants' self-fulfilment and development of skills required for their intrafamilial interaction.

The first stage involved evaluation of the initial level along with development of subjective well-being, value orientations and life meanings of the participants as well as development of such a system of spouses' interpersonal relationships that would facilitate their interaction, mutual understanding and respect. The second stage was directed at emotional concentration on value and meaning features of their marital life, activation of self-cognition, selfactualisation, development of personal communicative abilities, nonverbal communication skills, effective listening and understanding of the spouse. This stage was focused on value and meaning components of self-consciousness, beliefs and feelings developed before aimed at the formation of adaptive models of behaviour. The purpose of the third stage was to form unbiased assessment of a conflict situation, the ability to defuse tension in familial interaction of a married couple, which contributed to the overcoming of egocentrism, the formation of social reflexion, the development of motivational orientation at spouse's interests and mutual interaction.

The following methods appeared to be efficient for implementing the tasks of the psychocorrectional programme: group discussion, role playing, psychotechnic exercises including self-cognition exercises taken from psychosynthesis techniques, visualisation, projective drawing, "arete psychotherapy" developed by A. Yarotskyi (applied for treating various somatic diseases by means of enriching patients' lives with spiritual ideals), integrative psychotherapy, comprehensive marriage and family therapy, individual and group work, and work in pairs.

Efficiency of the programme procedures was assessed by comparing the data obtained at the formative stage of the experiment with the results of its summative stage. The analysis has shown that after the formative impact there has been observed statistically significant positive dynamics in the experimental group according to all the parameters of subjective well-being of a married person. In particular, the indexes of the scales "Adaptedness" (U=263; $p=0.006)$, "Self-acceptance" (U=266; $\mathrm{p}=0.007)$, "Acceptance of others" $(\mathrm{U}=252 ; \mathrm{p}=0.004)$, "Emotional Comfort" ( $U=216 ; \mathrm{p}=0.003)$, "Internality $(\mathrm{U}=259 ; \mathrm{p}=0.004)$ have increased, while the indexes of the scales "Satisfaction with Current Life" (U=314; $\mathrm{p}=0.034)$, "Optimism" (U=584; 0.045), and "Hope for the Future" (U=596; $\mathrm{p}=0.042)$ have increased noticeably.

A statistically significant positive dynamics has been observed according to the scales of "Moral Motivation" (U=641; $p=0.005)$, "Positive Estimation of one's Health" ( $U=677$; $\mathrm{p}=0.001$ ), self-fulfilment scales at the operational level, the level of values and role sets. There has been found a statistically significant increase of the level of satisfaction with marriage when comparing the results of the first and second diagnostic assessment $(\varphi=1.56 ; p \leq 0.05)$. The number of the study participants with the low level of satisfaction with marriage reduced by $26.4 \%$, while the number of people with medium and high levels of satisfaction with marriage increased by $10.6 \%$ and $15.8 \%$ respectively. The number of interpersonal conflicts in marriage reduced significantly $(\varphi=2.14 ; p \leq 0.01)$. No statistically significant changes of the above-mentioned indexes in the control group have been found. The results of comparative analysis are represented in the Table 1 .

The results of the formative stage of the study have confirmed the effectiveness of the integrated programme of socio-psychological support of subjective well-being of a married person and its capability to increase the level of satisfaction with marriage among the study participants, overcome the consequences of experiencing subjective illbeing by a personality in the system of interpersonal interaction in marriage.

Efficiency of the programme implementation was provided by the principles of its organisation (integrity and self-sufficiency, modularity, flexibility, differentiation, orientation at personal acceptance) and functioning (openness, consistency, controllability, dialogic character, phasing; orientations at self-development, conscious solving of the problems related to experiencing subjective ill- 
being in marriage, correspondence of forms and methods of counselling, psychocorrection and psychotherapy).

\section{Conclusions}

Qualitative and quantitative analysis of the data obtained after formative impact makes it possible to conclude that the chosen methods of psychological aid in socio-psychological support of subjective well-being of a married person are effective for solving the following problems: increasing the level of emotional comfort; selffulfilment in marriage at the operational level, the level of values and role sets; optimism; moral motivation; devel- opment of reflexion, internality, self-analysis skills, the ability to differentiate and express one's emotions; expanding the experience in conflict-free communication in the system of interpersonal familial role-based interaction of spouses, orientation at self-actualisation; increasing the general integrated index of satisfaction with marriage.

Further studies will be targeted at investigating the peculiarities of dynamics and ways of increasing the level of productivity of personal aspirations in counselling and psychocorrectional work in terms of experiencing personality's subjective well-being.

Comparison of the basic parameters of subjective well-being of married people under study before and after the formative impact

\begin{tabular}{|l|c|c|c|c|}
\hline \multicolumn{1}{|c|}{ Parameters } & EG & CG & U & p \\
\hline Self-fulfilment in marriage at the operational level & 42.334 & 47.181 & 312 & 0.04 \\
\hline Self-fulfilment in marriage at the level of values & 40.046 & 49.694 & 308 & 0.03 \\
\hline Self-fulfilment in marriage at the level of role sets & 41.922 & 56.664 & 246 & 0.002 \\
\hline Adaptedness & 44.743 & 55.688 & 263 & 0.006 \\
\hline Self-acceptance & 47.081 & 53.210 & 266 & 0.007 \\
\hline Acceptance of others & 46.454 & 57.336 & 252 & 0.004 \\
\hline Emotional comfort & 37.938 & 48.188 & 216 & 0.003 \\
\hline Internality & 54.986 & 67.672 & 259 & 0.004 \\
\hline Internal control & 53.265 & 52.389 & 640 & 0.003 \\
\hline External control & 48.549 & 58.678 & 312 & 0.037 \\
\hline Escapism & 52.705 & 47.280 & 597 & 0.041 \\
\hline Satisfaction with current life & 43.385 & 49.536 & 314 & 0.034 \\
\hline Optimism & 46.402 & 53.945 & 584 & 0.045 \\
\hline Hope for the future & 57.722 & 48.276 & 596 & 0.042 \\
\hline Positive assessment of one's own health & 53.458 & 60.848 & 677 & 0.001 \\
\hline Conflict proneness & 55.109 & 64.502 & 567 & 0.043 \\
\hline Moral motivation & 56.143 & 61.567 & 641 & 0.005 \\
\hline Satisfaction with marriage (according to CSM) & 52.475 & 63.984 & 576 & 0.047 \\
\hline Satisfaction with marriage (according to IFC) & 48.236 & 52.184 & 643 & 0.008 \\
\hline
\end{tabular}

Note: CSM - Checklist of Satisfaction with Marriage; IFC - Interpersonal Family Conflict (questionnaire)

\section{REFERENCES}

1. Abulkhanova-Slavskaya, K. A. (1991). Strategiya zhizni [Strategy of life]. Moscow: Mysl [in Russian].

2. Brynza, I. V., Ryazantseva, Ye. Yu. (2008). Problema issledovaniya resursov lichnosti $\mathrm{v}$ psikhologicheskoy nauke [Study of personal resources in psychology]. Aktualni problemy psykholohii Institutu psikholohii im. H. S. Kostiuka: zb. nauk. prats - Topical issues of psychology: collection of scientific works of G. S. Kostiuk Institute of Psychology, 6, 126-130. S. D. Maksimenko, M. V. Papucha (Eds.) Kyiv-Nizhyn [in Russian].

3. Vasilyuk, F. Ye. (1995). Zhiznennyi mir i krizis: Tipologicheskii analiz kriticheskikh situatsiy [Life and crisis: typological review of crisis situations]. Psikhologicheskiy zhurnal-Psychological journal, 3, 90- 101 [in Russian].

4. Chepelieva, N. V., Smulson, M. L., Zazymko, O. V., Hutsol, S. Yu. et al. (2016). Samoproektuvannia osobystosti u dyskursyvnomu prostori: monohrafiia [Selfdesigning of a personality in the discursive space: monograph]. Kyiv: Pedahohichna dumka. Retrieved from: http://lib.iitta.gov.ua/704560/ [in Ukrainian].

5. Smulson, M. L. (2014). Mistse samoproektuvannia u proektnii paradyhmi [Place of self-designing in the design paradigm]. Aktualni problemy psykholohii: zb. nauk. prats Instytutu psykholohii im. H. S. Kostiuka NAPN Ukrainy - Topical issues of psychology: collection of scientific works of G. S. Kostiuk Institute of Psychology, 8, 16-29. Zhytomyr: Vydavnytstvo ZhDU im. I. Franka [in Ukrainian].

6. Tytarenko, T. M., Kochubeinyk, O. M. \& Cheremnykh, K. O. (2014). Psykholohichni praktyky konstruiuvannia zhyttia $v$ umovakh postmodernoi sotsialnosti: monohrafiia [The psychological practice of designing life in postmodern sociality: monograph]. Kyiv: Milenium [in Ukrainian].

7. Fridman, Dzh, \& Kombs, Dzh. (2001). Konstruirovanie inykh realnostey. Istoriya $i$ rasskazy kak terapiya [Construction of other realities. The history and stories as a therapy]. Moscow: Klass [in Russian].

8. Chepelieva, N. V. (2014). Rozuminnia ta interpretatsiia zhyttievoho dosvidu yak chynnyk samoproektuvannia osobystosti [Understanding and interpretation of life experience as a factor personality's self-designing]. Nauka i osvita: naukovo-praktychnyi zhurnal Pivdennoukrainskoho natsionalnoho pedahohichnoho universytetu imeni K. D. Ushynskoho - Science and education: academic journal of South Ukrainian National Pedagogical University named after K. D. Ushynsky, 9/CXXYI, 22-25 [in Ukrainian].

9. Schukina, M. A. (2014). Napravleniya issledovaniy samorazvitiya $\mathrm{V}$ sovremennoy zarubezhnoy psikhologii [Research areas of self-development in con- 
temporary foreign psychology]. Voprosy psikhologii -

\section{ЛІТЕРАТУРА}

1. Абульханова-Славская К. А. Стратегия жизни / К. А. Абульханова-Славская. - М. : Мысль. 1991.-301с.

2. Брынза И. В. Проблема исследования ресурсов личности в психологической науке / И. В. Брынза, Е. Ю. Рязанцева // Актуальні проблеми психології Інституту психології ім. Г. С. Костюка : зб. наук. праць [за ред. С. Д. Максименка, М. В. Папучі]. Київ- Ніжин. 2008. - Т. 10. - Вип. 6. - С.126.

3. Василюк Ф. Е. Жизненный мир и кризи : Типологический анализ критических ситуаций / Ф. Е. Василюк // Психологический журнал. -1995. - №3. - С.90-101.

4. Самопроектування особистості у дискурсивному просторі : монографія [Електронний ресурс] / Н. В. Чепелєва, М. Л. Смульсон, О. В. Зазимко, С. Ю. Гуцол [та ін.] ; за ред. Н. В. Чепелєвої. - К. : Педагогічна думка, 2016. - С 6. - Режим доступу : http://lib.iitta.gov.ua/704560/

5. Смульсон М. Л. Місце самопроектування у проектній парадигмі / М. Л. Смульсон // Актуальні проблеми психології : зб. наук. праць Інституту пси-
Psychological issues, 4, 94-106 [in Russian].

хології ім. Г. С. Костюка НАПН України. - Житомир : Видавництво ЖДУ ім. І. Франка. - 2014. - Т. ІІ. Психологічна герменевтика. - Вип. 8. - С. 16-29.

6. Титаренко Т. М. Психологічні практики конструювання життя в умовах постмодерної соціальності : монографія / Т. М. Титаренко, О. М. Кочубейник, К. О. Черемних. - К. : Міленіум, 2014. - 206 с.

7. Фридман, Дж. Конструирование иных реальностей. История и рассказы как терапия / Дж. Фридман, Дж. Комбс. - М. : Класс, 2001. - 362 с.

8. Чепелєва Н. В. Розуміння та інтерпретація життєвого досвіду як чинник самопроектування особистості / Н. В. Чепелєва // Наука і освіта. Науковопрактичний журнал Південноукраїнського національного педагогічного університету імені К. Д. Ушинського. - № 9/CXXYI. - 2014. - С. 22-25.

9. Щукина М. А. Направления исследований саморазвития в современной зарубежной психологии / М. А. Щукина // Вопросы психологии. - 2014. - № 4. - C. 94-106.

\section{кандидат психологічних наук, дочент кафедри практичної падим Юрійович Завацький, Східноукраїнський начіональний університет імені В. Даля, просп. Центральний, 59 А. м. Севєродонеиьк. Україна. Анатолій Апсентійович Ткач. доктор хабілітований, професор кафедри економічної теорї̈ факильтетv vправління. Політехнічний університет імені Ігначія Лукашевича, вул. Варшавського повстання, 12 35-959, м. Жешув, Польща, Андрій Юрійович Федоров, проректор, Східноукраӥнський національний університет ім. В. Даля, просп. Центральний, 59А, м. Сєвєродонецьк, Украӥна}

\section{СОЦАЛЬНО-ПСИХОЛОГІЧНІ ЗАСАДИ ПІДТРИМКИ СУБ'ЄКТИВНОГО БЛАГОПОЛУЧЧЯ ОСОБИСТОСТІ В УМОВАХ СУЧАСНОГО СОЦІУМУ}

Актуальність вивчення проблеми соціально-психологічних особливостей підтримки суб'єктивного благополуччя особистості розглядається в умовах проблемогенного спектру сучасного трансформаційного соціуму. Метою дослідження $\epsilon$ аналіз принципів побудови та функціонування інтегрованої соціально-психологічної програми підтримки суб'єктивного благополуччя особистості в шлюбі. Основним завданням наукового пошуку є визначення змісту й ефективності впровадження інтегрованої соціально-психологічної програми підтримки суб'єктивного благополуччя особистості в шлюбі. Під час реалізації розробленої психокорекційної програми ефективними виявилися такі методи: рольова гра, психотехнічні вправи, зокрема, вправи на самопізнання з арсеналу технік психосинтезу, візуалізація, проективний малюнок, інтегративна психотерапія, системна сімейна психотерапія, індивідуальні та групові форми роботи. Проведений якісний та кількісний аналіз отриманих даних дозволяє стверджувати, що обрані методи психологічної допомоги у соціально-психологічній підтримці суб'єктивного благополуччя особистості в шлюбі виконують такі завдання: підвищення ступеня емоційного комфорту; самореалізації в шлюбі на операціональному рівні, рівні цінностей та рольових установок; оптимізму, моральної мотивації, розвитку рефлексії, інтернальності, навичок самоаналізу, вміння диференціювання й виразу своїх почуттів, розширення досвіду безконфліктного спілкування в системі міжособистісної сімейнорольової взаємодії подружжя, спрямованості на самоактуалізацію, зростання загального інтегрального показника задоволеності шлюбом. Таким чином, отримані результати формувального етапу дослідження підтвердили ефективність інтегрованої програми соціально-психологічної підтримки суб’єктивного благополуччя особистості в шлюбі, іï спроможність підвищувати рівень задоволеності шлюбом у досліджуваних та можливість долати наслідки переживання суб'єктивного неблагополуччя особистості в системі міжособистісної взаємодії подружжя.

Ключові слова: особистість, суб'єктивне благополуччя, психологічне консультування, психокорекція, психотерапія.

Submitted on February, 10, 2017 